\title{
THE THREAT TO THE CEYLON ELEPHANT
}

\section{By A. M. Morgan-Davies}

For a number of reasons peculiar to Ccylon it is a practical impossibility to make anything but a very approximate estimate of the total elephant population of this island. In 1950, however, the warden of the Department of Wild Life announced the total population to be not much in excess of 1,000 animals; and if we are to work on any figure in assessing the present and future population trend, we must accept this estimate. The warden states further that the annual net increase of the wild population is in the neighbourhood of 6 per cent to 7 per cent which allows for natural deaths, and according to this figure we should, at the close of 1957 , have had a total wild elephant population of about 1,500 animals. This, however, takes no account of the number of deaths by gunshot injuries, illicit captures, casualties during periods of intense drought, etc., that take place annually and do not seem to diminish over the years. The result is that, instead of a gradual increase or even the maintenance of a constant population, there is an annual net decrease of approximately thirty animals.

The following table illustrates the yearly estimated wild elephant population over the past seven years, from an estimated total population of 1,000 animals at the beginning of 1951 to 780 animals at the close of 1957.

\begin{tabular}{|c|c|c|c|c|c|}
\hline $\begin{array}{c}\text { A } \\
\text { Ycar }\end{array}$ & $\begin{array}{c}\text { B } \\
\text { Estimnted } \\
\text { population }\end{array}$ & $\begin{array}{c}\mathbf{C} \\
\text { Annual } \\
\text { incrense at } \\
6 \text { per cent }\end{array}$ & $\begin{array}{c}\text { D } \\
\text { Theoretical } \\
\text { population } \\
(\mathbf{B}+\mathbf{C})\end{array}$ & $\begin{array}{c}\text { E } \\
\text { Killings }\end{array}$ & $\begin{array}{c}\mathrm{F} \\
\text { Estimated true } \\
\text { population } \\
\text { (carried to } \mathrm{A} \text { ) }\end{array}$ \\
\hline $\begin{array}{l}1051 \\
1052 \\
1053 \\
1054 \\
1055 \\
1050 \\
1057\end{array}$ & $\begin{array}{r}\mathbf{1}, 000 \\
030 \\
021 \\
80.4 \\
\mathbf{8 0 7} \\
\mathbf{8 3 5} \\
\mathbf{8 0 0}\end{array}$ & $\begin{array}{l}60 \\
50 \\
55 \\
54 \\
52 \\
50 \\
48\end{array}$ & $\begin{array}{r}1,060 \\
005 \\
070 \\
0.48 \\
010 \\
885 \\
85.4\end{array}$ & $\begin{array}{r}121 \\
74 \\
82 \\
81 \\
8.4 \\
70 \\
74\end{array}$ & $\begin{array}{l}030 \\
921 \\
80.4 \\
807 \\
835 \\
800 \\
780\end{array}$ \\
\hline
\end{tabular}

From these figures two points become alarmingly obvious; firstly, that the total number of killings recorded over the past seven years is more than 50 per cent above the annual increase and, secondly, that if the present number of killings is allowed to continue, extinction of the species will follow within the next thirty years.

It is well known that once a species has decreased to a certain 
number, breeding falls off and extinction follows. In the case of the Ceylon elephant this biological limit may not be far off, for the opening up of jungle land and the consequent dispersal, separation and isolation of herds and single animals aggravates the position; so that the whole ecological pattern and breeding potential is rapidly affected. In fact extinction may well take place in far short of thirty years.

There is no doubt at all that the survival of the Ceylon elephant rests largely in the hands of the village cultivator who can well be saddled with the responsibility for the slaughter of more than 300 animals over the past seven years. Before the introduction of firearms the cultivator relied on an organized system of crop protection by means of fires, drums and the human voice. With the appearance of cheap firearms and torch lights he has abandoned this innocuous method of protecting his crops and instead of keeping a watchful vigil throughout the night, merely shoots at the trespassing animal and goes back to sleep. Unless the animal happens to carry ivory the incident is promptly forgotten; the perpetrator has not violated any law and no thought is given to the sufferings of the shot animal. As long as it is no offence to kill an elephant in defence of crops, the cultivator will not adopt any other form of protection and the present excessive rate of killings will continue.

The continued existence of Ceylon's wild life and of its elephants in particular, is clearly conditional on the security provided by its habitat, and is the raison d'être for the establishment of suitable national parks and reserves. In countries where such parks and reserves are established by adequate long-term legislation, e.g. a National Trust, continuity is reasonably assured; but where, as in Ceylon, they are by no means free from interference, as exemplified by the excisions of large extents from time to time, there can be no permanent security, at any rate not for the elephant population.

The Department of Wild Life is fully alive to the gravity of the situation and is doing all within its powers to preserve the few remaining animals, but its work will be of no avail if the Government does not take immediate and adequate steps to change the existing law and thereby afford better protection to the Ceylon elephant.

\section{REFERENCES}

Nicholas, C. W., 1052. Administration Report of the Warden, Department of Wild Life for 1051.

IIolsies, C. II., 1057. Administration Report of the Warden, Department of Wild Life, for 1050. 